prospective targets?

They were not his affair; they merely gave a fillip of derring-do to what was. Disembarked at the convoy's first stop. he heard other evidence of confused times, amidst which, it seems, counterfeiters always thrive. Before dropping into the till his five silver cart wheels $(\$ 5$ Mex) for a first round of drinks, Old Man O'Brien's Chinese bartender plunked them one by one on an oblong stone set into the bar top. It was the newcomer's introduction to the then ubiquitous sounding-stone of Chinese retail trade. At his request the barkeep fished out a shining cartwheel from under the till to demonstrate the difference between its spurious responses and the authentic ring of silver.

"(Do men know where to find such a girl?') I've had no personal experience. but I did learn something about this from others.... They told me the ways you could tell whether a girl was a roadșide chicken. Only insiders knew."

Imagine that! Even a newcomer quickly had personal experiences in how not to find such a girl-if, indeed, the hunger-blurred eyes from whose mute solicitation one averted his own were those of a girl and not of an old woman. At dusk they used to swarm like mosquitoes to the brightly lit entrances of bars, restaurants, and dance-halls. There they:would be brushed back into the shadows by a Sikh watchman's rattan stick. It turned every way to guard the trees of life. When they emerged, especially American seamen, the shadows would stir in anticipation of flung handfuls of brass coins to be scrambled for.

What did the Londons seek to prove by evidences of furtive prostitution in the Peoples' Republic? Decay of sexual morals after the Cultural Revolution? "(Then, would you say that such girls [dropouts from "inferior" schools during that period] later became prostitutes not for economic reasons, but because they enjoyed that life-style?)"

"Inferior"' schools? Life-style! How one wishes that the Londons could have seen those stwarms, not of "lighthearted and optimistic" road chickens but blurry mosquitoes, that drifted through Shanghai dusks and were, reportedly, still doing so when Chiang fled to Taiwan. Conceding that journalistic apologias for the Peoples' Republic have a false ring, so do the Londons' counterapologias fail to re- verberate authentically on history's sounding-stone. Both coinages are too much alloyed with forensic naivetés.

Peyton Bryan

Smithville, Texas

Miriam and Ivan D. London Respond: Is Mr. Bryan suggesting that today's roadside chickens have come a long way, baby, since yesterday's blurry mosquitoes? Or that our young interviewees are less real than fifty-year-old memories? We're a bit confused-even without gunboats.

\section{"Who Speaks for the Church?"}

To the Editors: A footnote to historyor at least to my personal history and the story of a book. One reviewer of my Who Speaks for the Church?Professor Roger Shinn of Union Theological Seminary-was discerning enough to note that I did not want my own (or any other) specific views on social and political questions to prevail at the Geneva Conference. Besides, I was not a voting member, expected no influence, exerted none. I came away distressed, not disgruntled.

Looking back through the file of articles and reviews stimulated by my little manifesto, I see again that many people wrestled with the issues 1 had raised. Evangelicals and liberals alike were troubled. Unfortunately, we do not have in this country-so far as I know-a Christian journal comparable to $\mathrm{Sh}^{\prime} m a$, a "journal of Jewish responsibility" edited by Eugene Borowitz, whose columns welcome and receive contributions from Orthodox, Conservative, and Reform alike, both rabbis and laypeople. Where's the horizontal ecumenism across the breadth of Christianity today, or the vertical ecumenism from grass roots to top?

I am concerned for Richard Neuhaus's future happiness. My book accomplished nothing; nor-I predict-will his article ("Toeing the Line at the Cutting Edge, $"$ Worldview, June). There is no way to stop a runaway trolley car, or much hope of turning it around. Institutions seem to have to wear out. Indeed, Constantinian sectarianism in secular clothing seems to have invaded the seminaries. Better to take the word of voices from the trolley (but not their meaning) when they tell us that the Holy Spirit is at work elsewhere.

The first hundred people out there who will read my rare book. to which Neuhaus drew attention in his article. can receive a copy by sending me 2.5 cents and a stamped. self-addressed envelope $7^{\prime \prime} \times 10^{\prime \prime}$.

Paul Ramsey

Department of Religion

Princeton University

Princeton, N.J.

\section{"The U.S. in Korea: What Price Security?'}

To the Editors: After reading Donald $\mathrm{L}$. Ranard's article in the January/ February issue ("The U.S. in Korea: What Price Security?"') I wondered whether people like him really care about the Korean people or whether they just care about abstract ideas while using this as an excuse for a U.S. pullout. If they really care about the human rights of South Koreans on which they constantly harp, wouldn't they want to give constructive help to these poor repressed people?

With a withdrawal, U.S. leverage on Park would lessen. and if you believe what people like Ranard write about Park, it seems he would become more repressive because he would be paranoid about his own and Korea's survival; with a takeover by the North it won't be a question of violations but of the complete extinction of human rights. At any rate, as most experts think, war will come and hundreds of thousands will die, and dead people don't enjoy human rights-at least in this world. How could this be a moral policy?

But I suspect that Mr. Ranard, as his recent telling of Japanese opposition leaders that the LDP is taking bribes from Korea shows, has other plans. With the LDP out, the Socialists will be in, and that would mean the U.S. couldn't use the Japanese bases for the defense of Korea and that the Japanese-Korean economic cooperation would end. So Korea would be left isolated, in economic trouble, and without U.S. ground troops. And the U.S. air units and the ROK forces would be tactically hard to resupply.

William M. Simonton

Searile, Wash. 